\title{
Socializing Your WebPAC
}

Graham McCarthy

Sally Wilson

Ryerson University

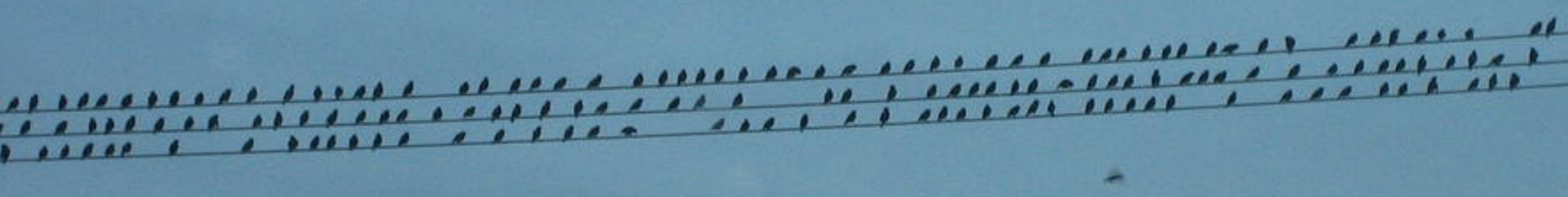

ECIUG, March 2008, University of Ottawa 


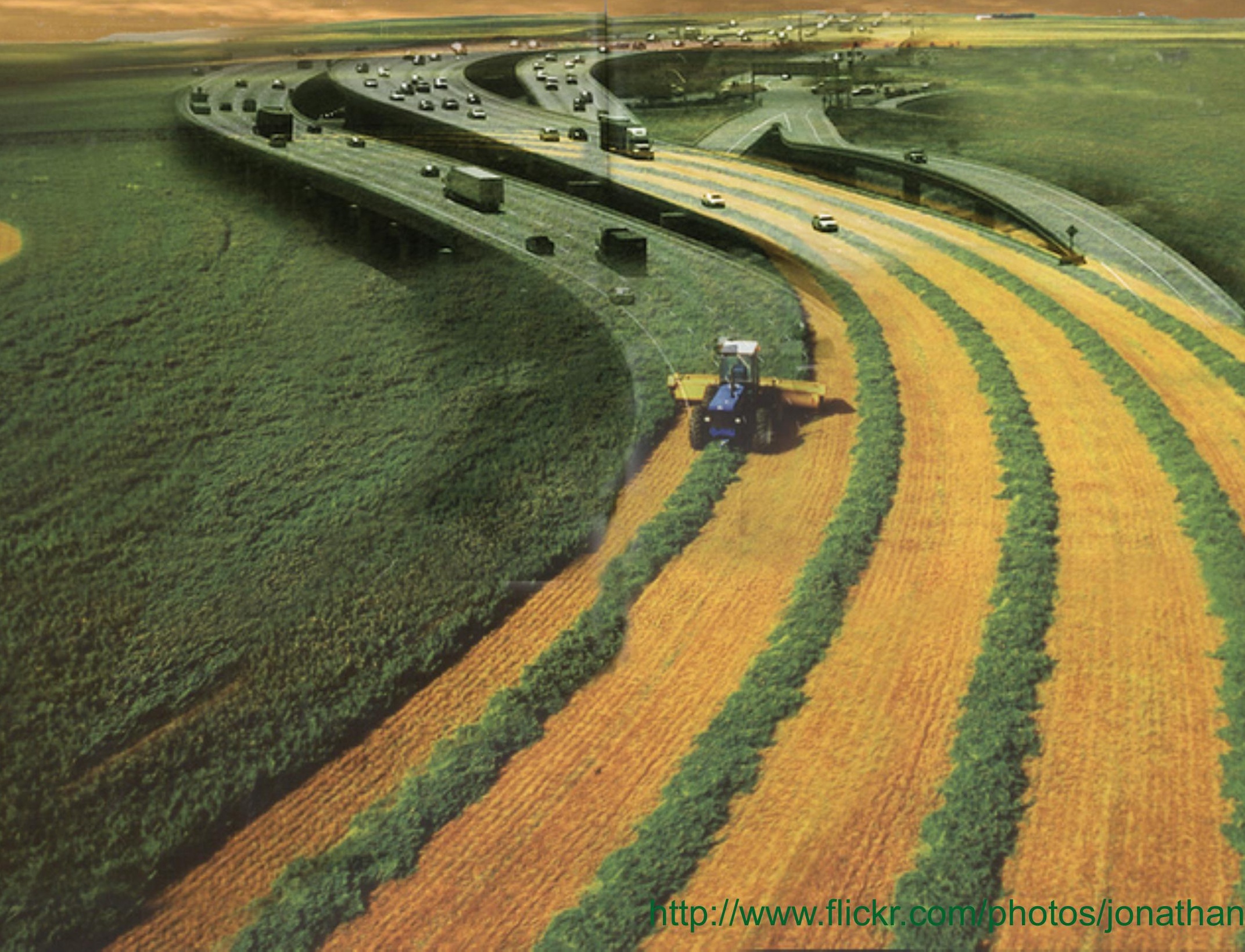




\section{Where do you typically begin your search for information on a particular topic?}

\section{College Students}

Search Engine $\quad 89 \%$

Library

$3 \%$

Members of the Public

Search Engine $\quad 84 \%$

Library

$1 \%$

Source: OCLC's Perceptions of Libraries and Information Resources, 2005 


\section{Searching behaviour}

-Power browsing

-Flicking, bouncing, skimming

-Horizontal info seeking

-Brand name reliance 


\section{Our Users}

\section{Promiscuous}

Diverse

Volatile 


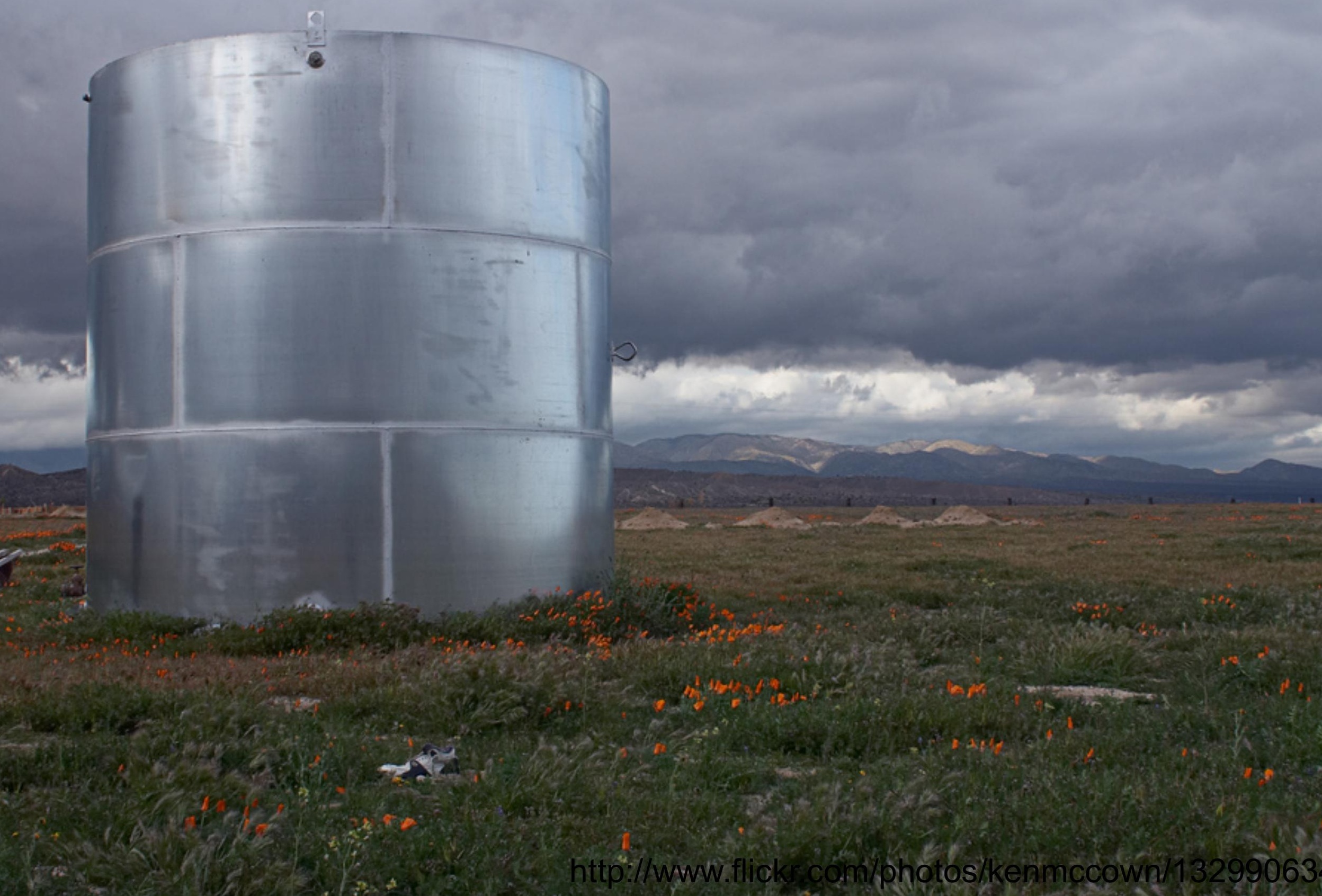



10

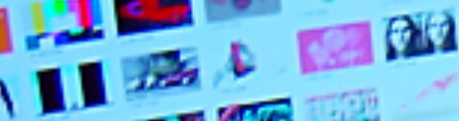

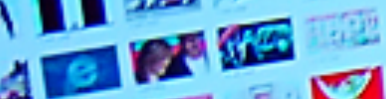

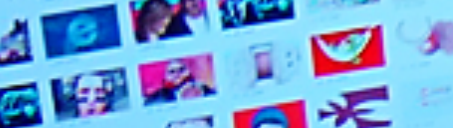
(5)

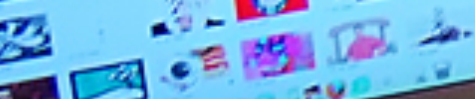

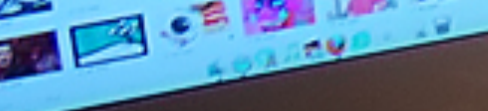

$4=100$

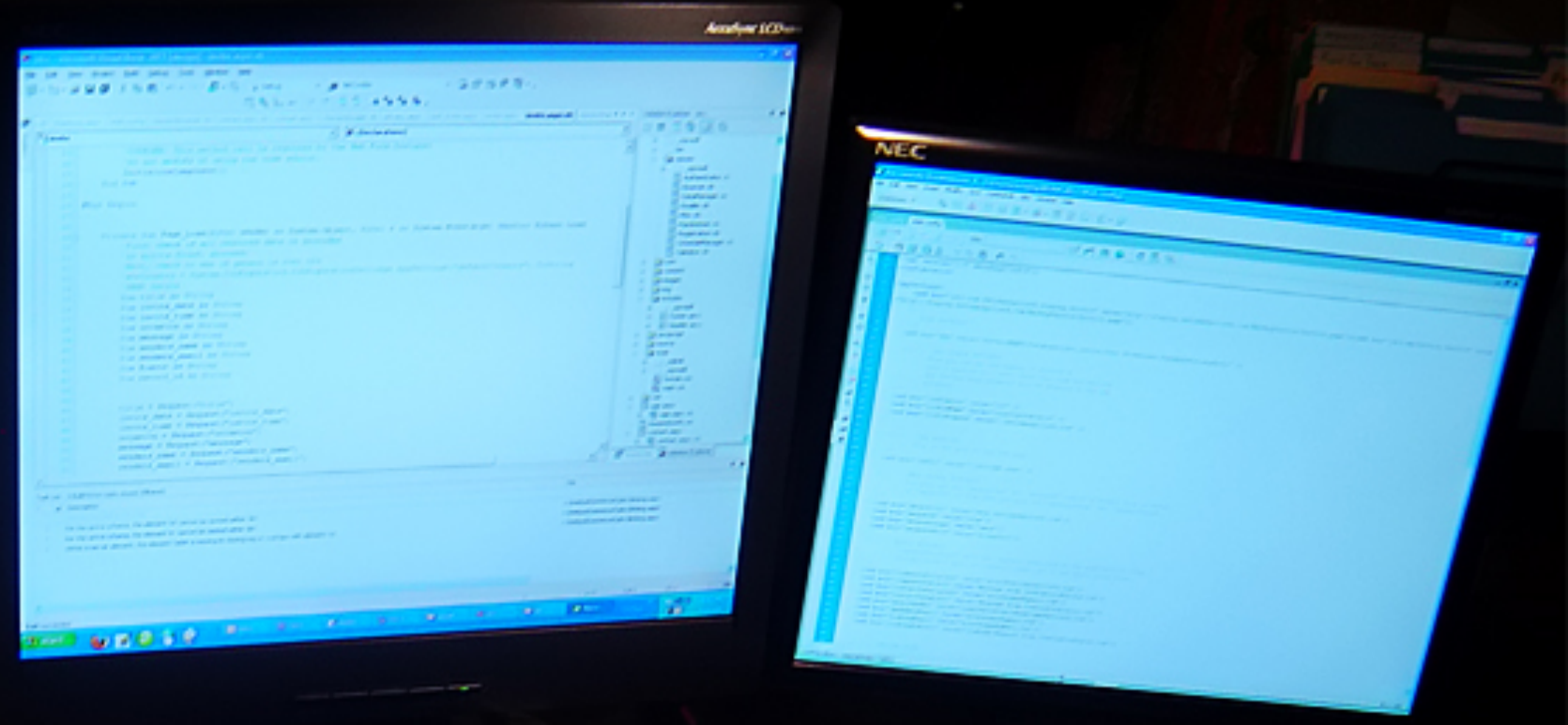
19.

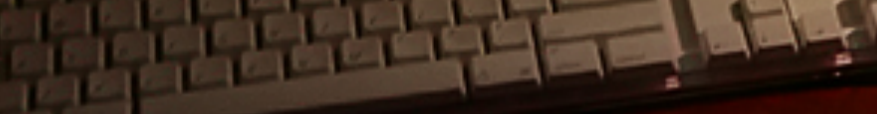

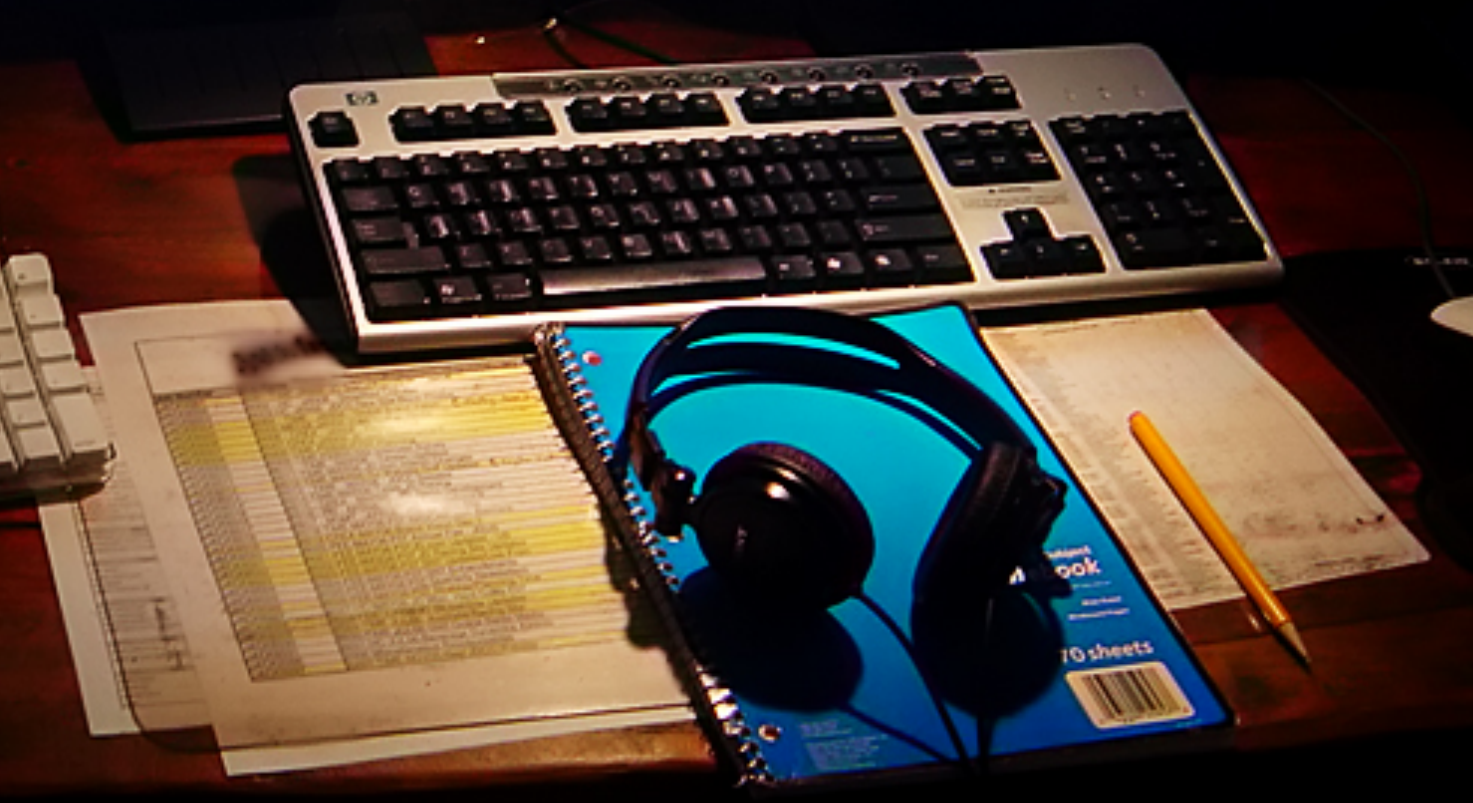

http://flickr.com/photos/ajoythomas/451412757 


\section{$\mathrm{Bb}$ Blackboard}

chapters.indigo.ca
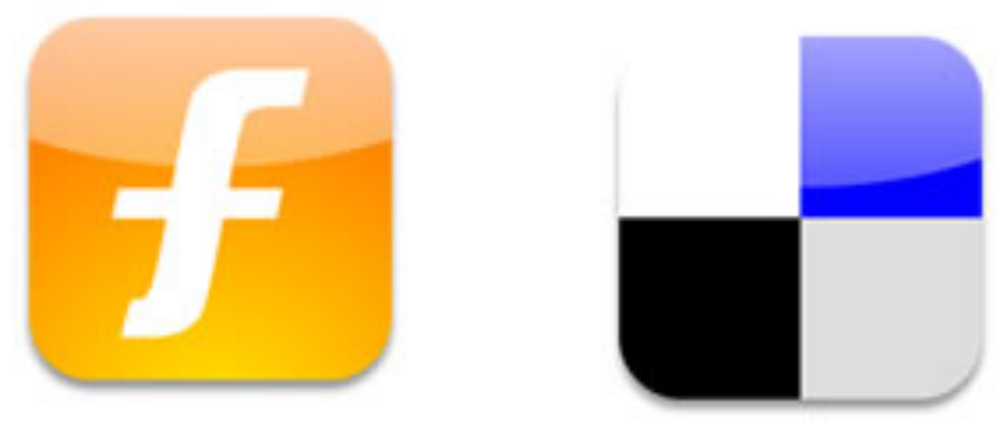

Share ff On Facebook

\section{facebook}

Send
via e-mail or
text message

†netvibes

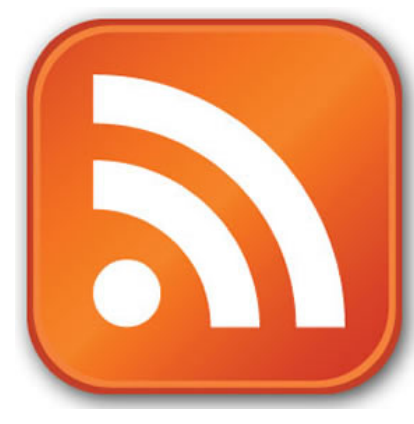

amazon.com.

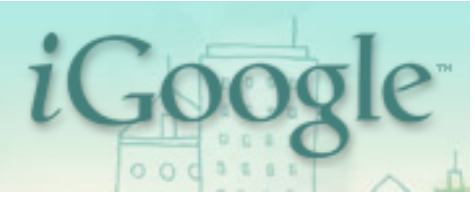




\section{facebook}

\section{Search $v$}

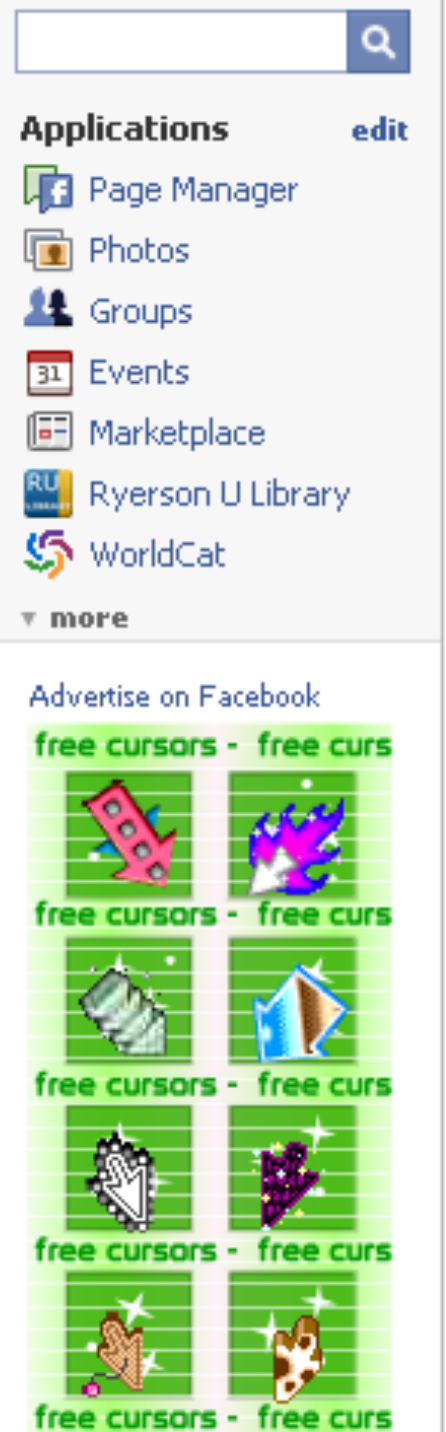

\section{Profile edit Friends $\boldsymbol{\nabla}$ Networks $\boldsymbol{\nabla}$ Inbox $\mathbf{v}$}

\section{News Feed}

Preferences

$\Omega$ Updated: Brian Cameron will be in a meeting for most of the day :-). 나

Yesterday

署 Corey Seeman took the position "Yes, those states deserve to represented" in the Debate Group Should the delegates from Florida and

Michigan be included in the nominating pool at the Democratic National

Convention?.

C6 The situation in Michigan is that no fair election was held. Obama and Edwards were not on the ballot and if you wrote them in, they would have been tossed.

Michigan should have meaningful content with debates and both the candidates on the ballot. Right now, we just have a mess. $y 3$

\section{ㅁ] Graham McCarthy posted a photo.}

$\mathbb{3} \mid x$

\section{img297.imageshack.us}

http://img297, imageshack .us/im...

as Sigh. . so true... I will never be that cool. :( . yg

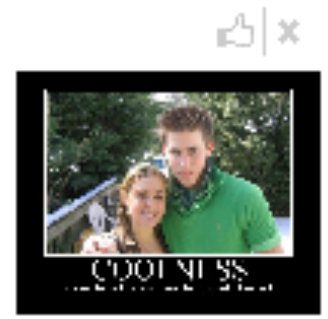

Add a comment | 2 comments

14 Jennifer Hagen joined the group Iain Barrie Quotes.

$3 \mid x$

阙 Ala Alan Miller wrote on your Wall.

S $\mid x$

C6 What, Edward Gorey is dead? We were going to retire together, to a trailer park in Arizona. $y$

Ge imiall-rn-imiall home account privacy logout

\section{Requests}

내, 2 friend requests

2 other requests

\section{Updates}

2 new updates

\section{Status Updates}

see all

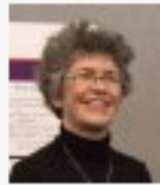

What are you doing right now?

show friend updates

\section{Birthdays}

see all

Today

Alan Miller

Sunday, February 24

Graham McCarthy

\section{Invite Your Friends}

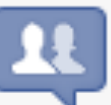

Invite your friends to join Facebook.

\section{New Stuff}

Today's Gift: (\$1 USD) 


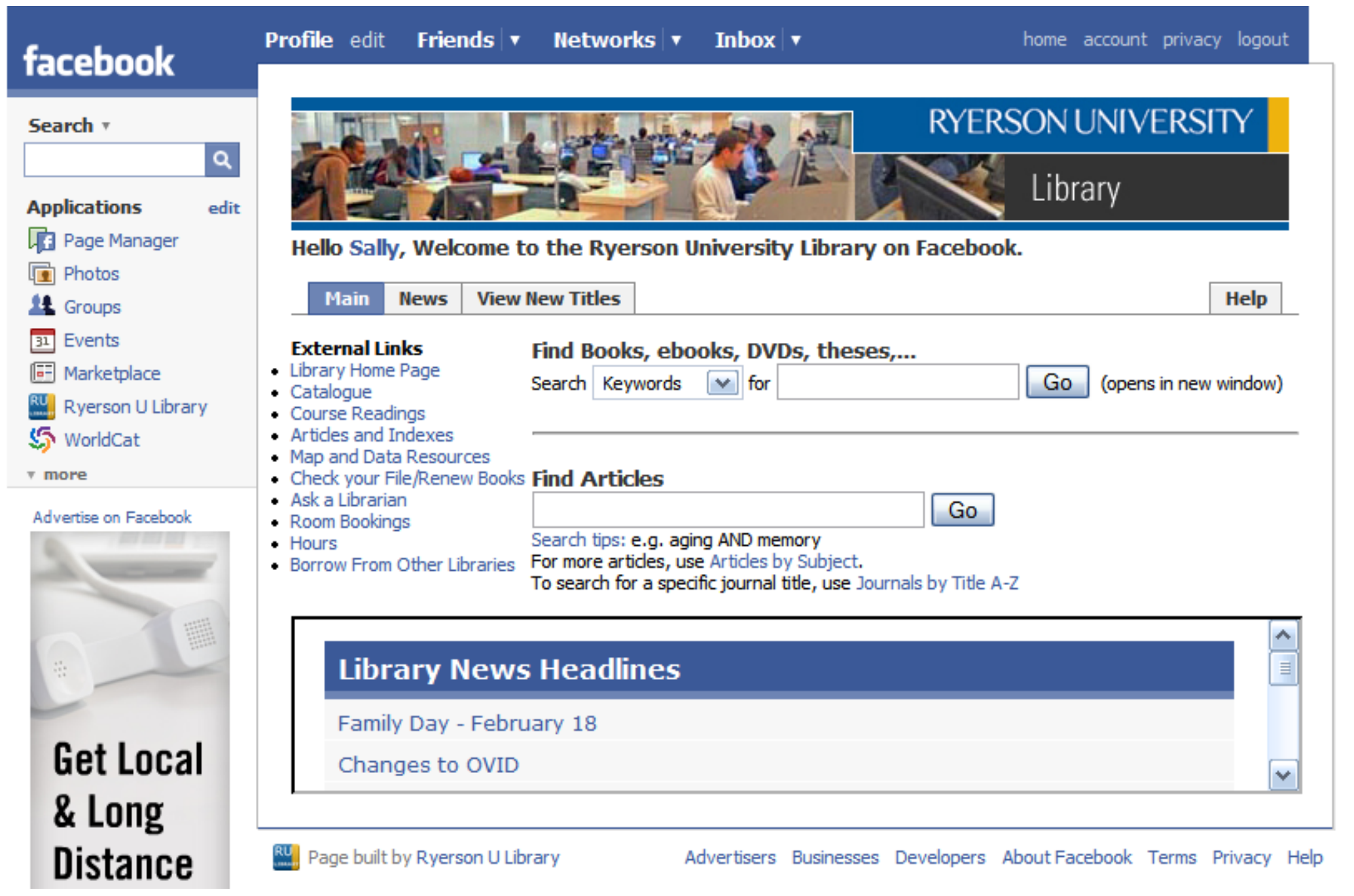




\section{RYERSON UNIVERSITY}

Catalogue

\section{Articles \&}

Indexes

Research Help

About the Lbrary/FAQ

Interlibrary Loans

\section{Map \& Data} Resources

Home $>$ Catalogue

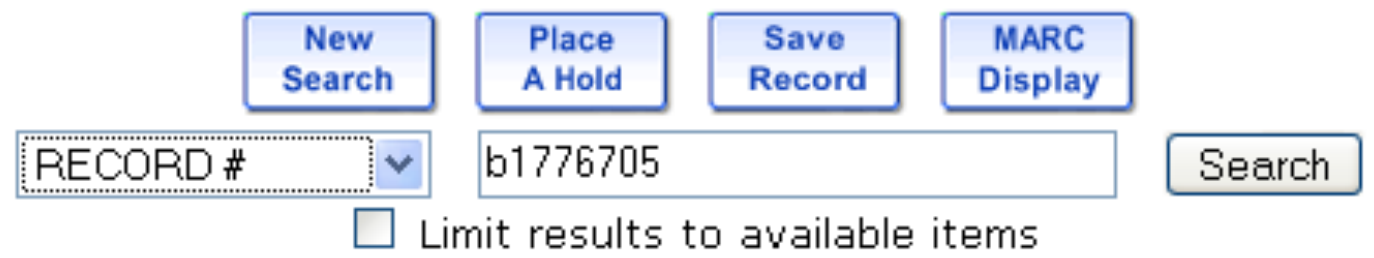

Author Newlands, Anne, 1952-

Title Canadian paintings, prints and drawings / Anne Newlands.

Publisher Richmond Hill, Ont. : Firefly Books, 2007.

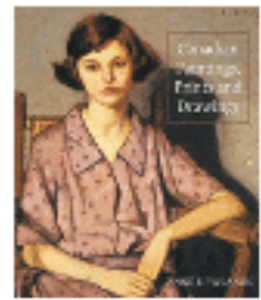

\section{LOCATION} 8th Floor

CALL \# ND240.N48 2007

Description $366 \mathrm{p}$. : col. ill. ; $29 \mathrm{~cm}$.

Notes Includes bibliographical references ( $p .355-356$ ) and index.

Subject Painting, Canadian.

Prints, Canadian.

Drawing, Canadian.

Artists -- Canada.

ISBN 9781554072903

1554072905

LCCN/NLC 20079013058
Add to

O RerWorks

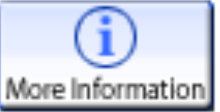

Send

via e-mail or

text message

Share $f$

On Facebook 


\section{facebook}

\section{Send a Message Post to Profile}

Choose a Thumbnail

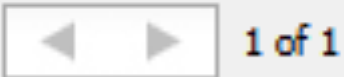

BLÂGK

witip

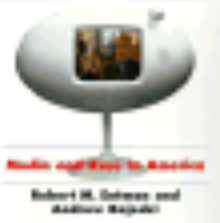

$\square$ No Picture

\section{Ryerson University Library}

1. The Racial Chameleon - 2. White Racial Attitudes in the Heartland - 3. Culture, Media, and the White Mind: The Character of Their Content - 4. The Meaning of Blackness in Network News - 5. Violence, Stereotypes, and African Americans in the News - 6. ... http://innopac, lib,ryerson,ca/recor... 


\section{facebook}

\section{Search $*$}

\section{Q}

\section{Applications}

edit

盾 Page Manager

[1] Photos

1. Groups

31 Events

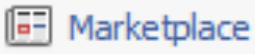

RL Ryerson U Library

(5) WorldCat

T more

Advertise on Facebook

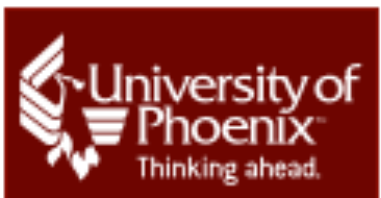

\section{$\overline{\text { ONLINE PROGRAMS }}$}

ASSOCIATE'S

DEGREES

Associate of Arts

in Business

Associate of Arts

in Health Care

\section{My Posted Items}

Displaying all 10 posted items.

收 You posted a link at 9:21am Jan 28.

\section{Ryerson University Library}

http://innopac, lib,ryerson,ca/...

Introduction / Rebecca Blood - 1. What the Hell Is a Weblog and Why Won't They Leave Me Alone? / Derek M. Powazek - 2. Weblogs: A History and Perspective / Rebecca Blood -3. Here Come the Weblogs / Jon Katz - 4. ...

\section{sis This may be a good source on blogging;} unfortunately it is out at the moment. $y$

Add a comment | No comments

证 You posted a link at 2:22pm Jan 7.

Ryerson University Library http://innopac, lib.ryerson.ca/...

Twenty-eight anecdotal stories that chronicle men, women, and children involved in every aspect of the African AIDS

\section{Post a link}

http://

Post

Share on Facebook

Drag the button above to your Bookmarks Bar to quickly share content with your friends.

More details *

\section{Subscribe to Posted Items}

\$. My Posted Items

Subscription Help 9

\section{Posted Items Help}

Explore how Share works * Add Share to vour site $"$ 


\section{Facebook stats}

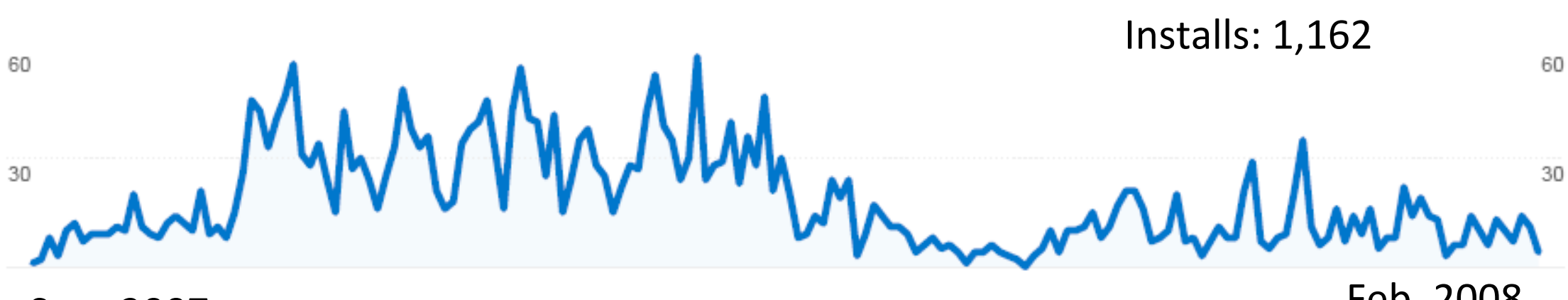

Sept 2007

Feb. 2008 


\section{Course Management Systems - Blackboard}

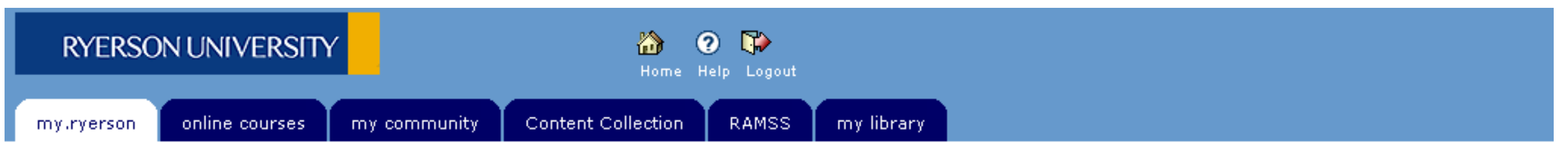

\section{Welcome, Sarah (Sally)}

Module Administrator Modify Content Modify Layout

\begin{tabular}{|c|}
\hline Tools \\
\hline Announcements \\
\hline 國 \\
\hline 畾 Tasks \\
\hline$\frac{\text { 呵 View Interim Marks }}{\text { for Online Courses }}$ \\
\hline [9] Address Book \\
\hline G Textbox Options \\
\hline
\end{tabular}

\section{Hot Links}

Web Mail

Faculty Course Survey

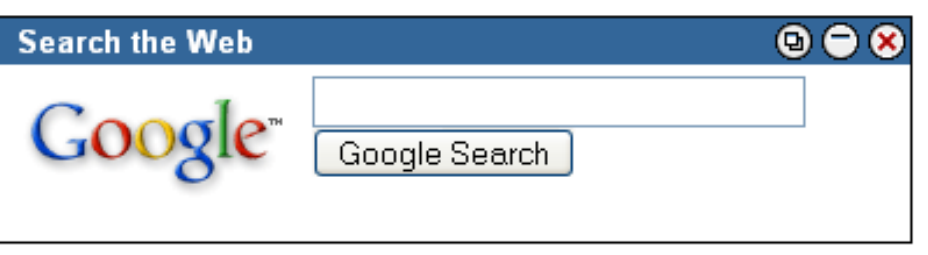

Online Courses

Courses you are teaching:

co Library Test Course

No Announcements.

My Organizations

Organizations in which you are participating:

9 Academic Integrity : Faculty Resources

a Blackboard 101

a ITMLIB

๓ RFA - Ryerson Faculty Association
Blackboard Admin Announcements

2008-01-02 Students: About Online Courses...

2007-10-19 IMPORTANT NOTICE : Problems with the text editor

[Admin Announcement Archives]

`Please note: Any listings marked 'Faculty/Staff' are meant for Ryerson Staff and Faculty only.

\section{Blackboard Support - Faculty \& Staff}

$\rightarrow$ Blackboard Staff and Faculty Support Website

$\rightarrow$ Request a Blackboard Course Shell

Ryerson Staff and Faculty can email us at courses@ryerson.ca or call the Help Desk at 979-5000 x6806.

$\Theta$

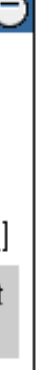




\section{RYERSON UNIVERSITY}

\section{my.ryerson}

\section{my library}

Hot Links

- Library Home Page

- Catalogue

- Course Readings

- Articles and Indexes

- Map and Data Resources

- Check your File/Renew

Books

- Ask a Librarian

- Room Bookings

- Hours

- Borrow From Other Libraries

\section{Ryerson Library - Quick Searches}

Find Books, ebooks, DVDs, theses,...

Search Keywords $v$ for Go

\section{Find Articles}

Search tips: e.g. aging AND memory

For more articles, use Articles by Subject.

To search for a specific journal title, use Journals by Title A-Z

\section{Ryerson Library Services for Faculty \& Staff}

- Place an item on Reserve

- Targeting Journals for Publication

- Suggest a Title for Purchase

- Find your Subject Librarian

- More services for Faculty

\section{Ryerson Library News}

- Family Day - February 18

- Changes to OVID

- iGoogle, NetVibes and the Library

- Ask Ontario Now Live

- Springer e-books

\section{$2.6 \%$ of traffic to catalogue comes from Blackboard}




\section{Personalized Home Pages - iGoogle, NetVibes}

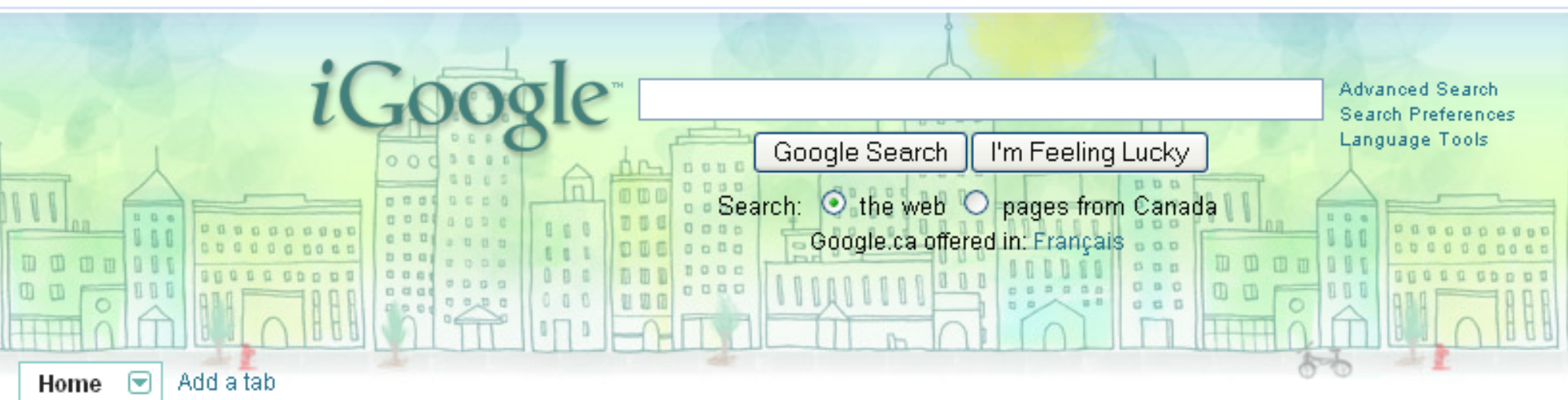

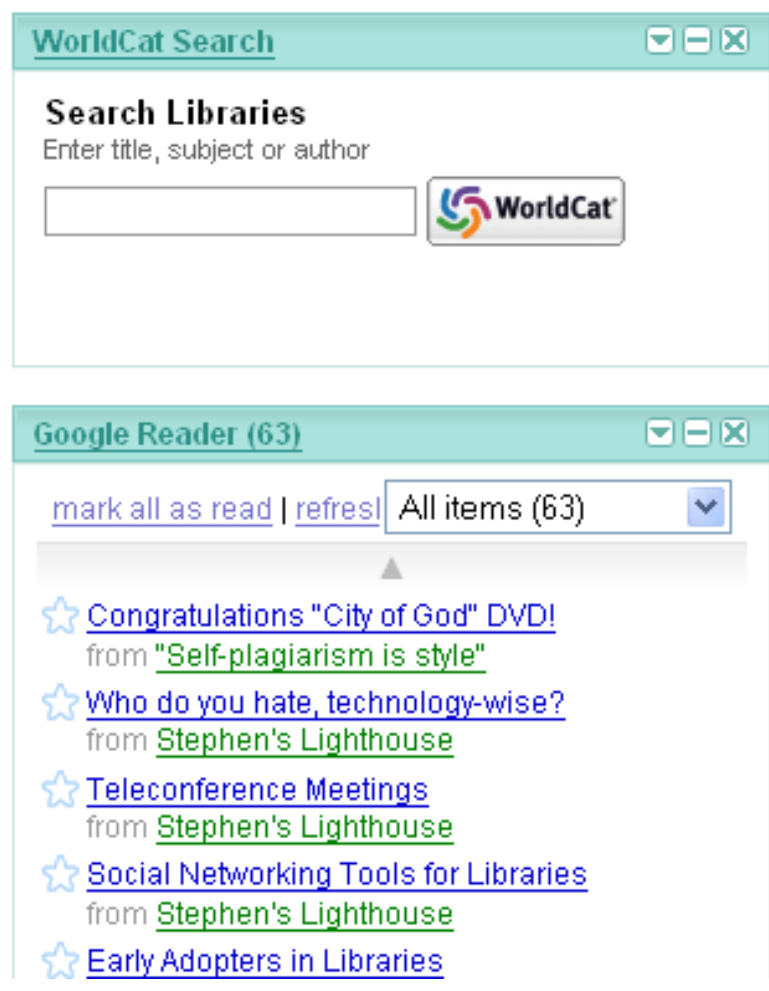

BBC News | News Front Page $\mid$ Wo
Edition
$\boxplus$ Turkish troops enter north Irag
$\boxplus$ Iran 'nuclear questions remain'
$\boxplus$ Castro 'relishes chance to rest'

\section{Gmail}

$\nabla \Theta \bar{x}$

Inbox (3) Hide preview Compose Mail

Google - Google Alert - "ryerson uniwersi

Google - Google Alert - "ryerson universi

Apple - iPod shuffle. Now just $\$ 49$. - Wh

Google - Google Alert - "ryerson universi

avocet, me, Geoff - (3) - Question about ?

$21 \mathrm{Feb}$

$20 \mathrm{Feb}$

20 Feb

19 Feb

19 Feb

Google Calendar

$\nabla \boxminus \bar{x}$

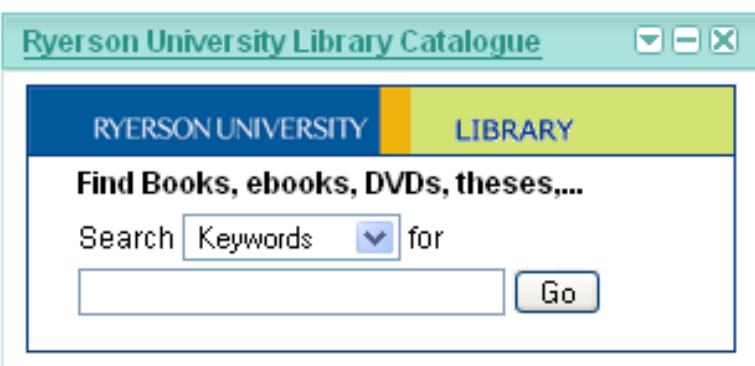

Weather $\nabla \boxminus \overline{\mathbf{x}}$

$\underline{\text { Toronto }}$

$-2^{\circ} \mathrm{C}$

Cloudy

Wind: NE at

$13 \mathrm{~km} / \mathrm{h}$

Humidity: $69 \%$
New! Select theme | Add stuff $n$

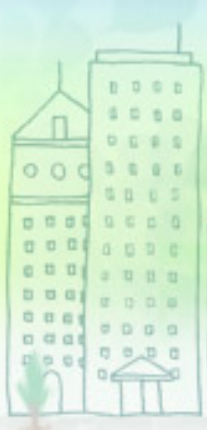




\section{Google}

\section{amazon.ca}

$$
\text { chapters.indigo.ca }
$$


chapters.indigo.ca

UP T0 80\% OFF!
Shopping Bag $\vdots$ Wish List $\vdots$ Your Account $\vdots$ Store Locator

$$
\text { Order Status | Sign Out | Help }
$$

WE HAVE

\begin{tabular}{|l|l|l|l|l|l|l|l|l|l}
\hline TOYS & DVDS & MUSIC & IPOD & GIFT CARDS & PHOTOBOOK & COMMUNITY & YOUR PROFILE \\
\hline
\end{tabular}

Browse Books Bestsellers Coming Soon Gift Certificates Love of Reading irewards Program $\underline{\text { Français }}$

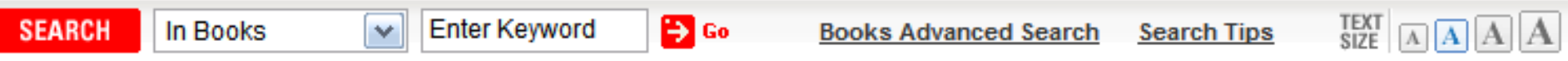

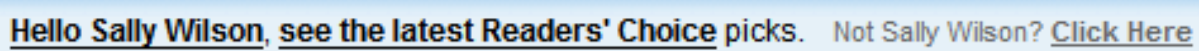

\section{A new tale of terror from Stephen King... pre-order DUMA KEY now! -}

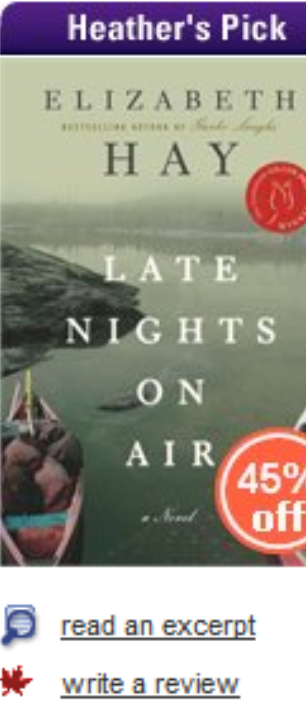

Heather's Pick

E L I Z A B E T H H A Y

$\approx \mathrm{L}$ A T E

N IG H T S

9 read an excerpt

* write a review

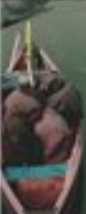

\section{Late Nights on Air}

Due back at the Ryerson University Library on 02-21-08

Author: Elizabeth Hay I See more titles by Elizabeth Hay

\section{ListPrice:}

Our Price:

You Save: $\$ 14.85(45 \%)$

irewards Member Price:

\section{In Stock}

Rate this Item

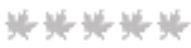

Rollover to choose rating

\section{$\$ 32.99$ \\ $\$ 18.14$ \\ $\$ 16.49$}

\section{Get it Used or Rare from \$36.16}

$\begin{array}{ll}\text { Average Customer Rating } & \text { Community Reviews } \\ 72 \text { ratings } & \underline{4 \text { reviews }} \\ & \text { write a review }\end{array}$

\section{Average C}

72 ratings

\section{READY TO ORDER?}

$\Theta$ Add to Shopping Bag

$\mathrm{g}^{\mathrm{x}}$ Add to Wish List

Shop with Confidence

\section{(14) Store Lookup}

Check if this product is available in our stores.

World's Biggest Book Store - Chapters

26 available

Faton Centre - Indino 


\section{Google Books}

Google Book Search

Search Books

swilson416@gmail.com | My library | My Account | $\underline{\text { Sign out }}$

About this book Preview this book The University of Toronto: A History Available in the Ryerson University Library! By Martin L. Friedland

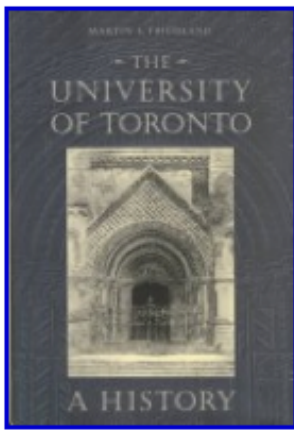

By Martin L. Friedland

Published 2002

University of Toronto

Press

History

600 pages

ISBN 0802044298

Add to my library

Write review

Preview this book
The University of Toronto is Canada's leading university and one of Canada's most important cultural and scientific institutions. Covering the history of the University from its origins as King's College in 1827 to the present, Martin Friedland weaves together personalities, events, and

intellectual ideas to create a scholarly, yet highly readable history that includes major figures such as Northrop Frye and Marshall McLuhan, and dramatic events such as the admission of women in the 1880 s, the University College fire of 1890 , the University's contributions during the First and Second World Wars, and the student protests of the 1960s. In researching and writing the book

Friedland drew on archival records, private diaries, oral interviews, and a vast quantity of secondary literature. He also drew on his own knowledge of the University as a student in the 1950 s, and later as a faculty member and dean of law who was involved in some of the issues he discusses. The history of the University of Toronto as described by Friedland is intimately connected with events outside the University. Transitions in Canadian society such as that from the early dependence on

Great Britain and fear of the United States to the present dominance of American culture and ideas can be seen mirrored in the

University. One can also trace the affects of the two World Wars, the Cold War, and the Vietnam War. As Canadian society and culture developed and changed through the latter half of the twentieth century, do too did the university: this university's history is the history of Canada and all Canadians. The first history of the university in seventy-five years, The University of Toronto: A History will be published

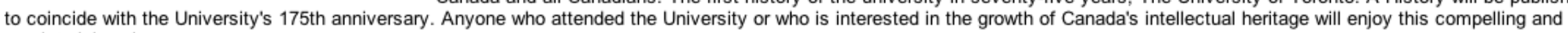
magisterial work.

\section{Contents}

2000 A Walk through the Campus

Bloor Street, Taddle Creek, University of Toronto

Principal Sources

Claude Bissell, Michiel Horn, Michael Bliss

\section{Bibliography}

\section{Picture Credits}

Jack Marshall, Lansdale, St Michael's College

Readers of the Complete Manuscript

ranara FRIFnI $\triangle \mathrm{NI}$ S Srhahac

\section{Selected pages}

667

683

697

715

723
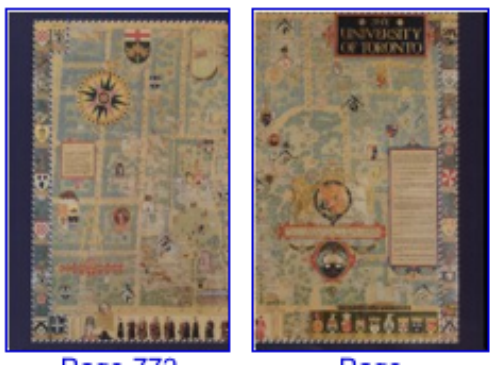

\section{Buy this book}

University of Toronto Press

Amazon.ca

Chapters.indigo.ca

\section{Borrow this book}

Find this book in a library 


\section{Indigo Search}

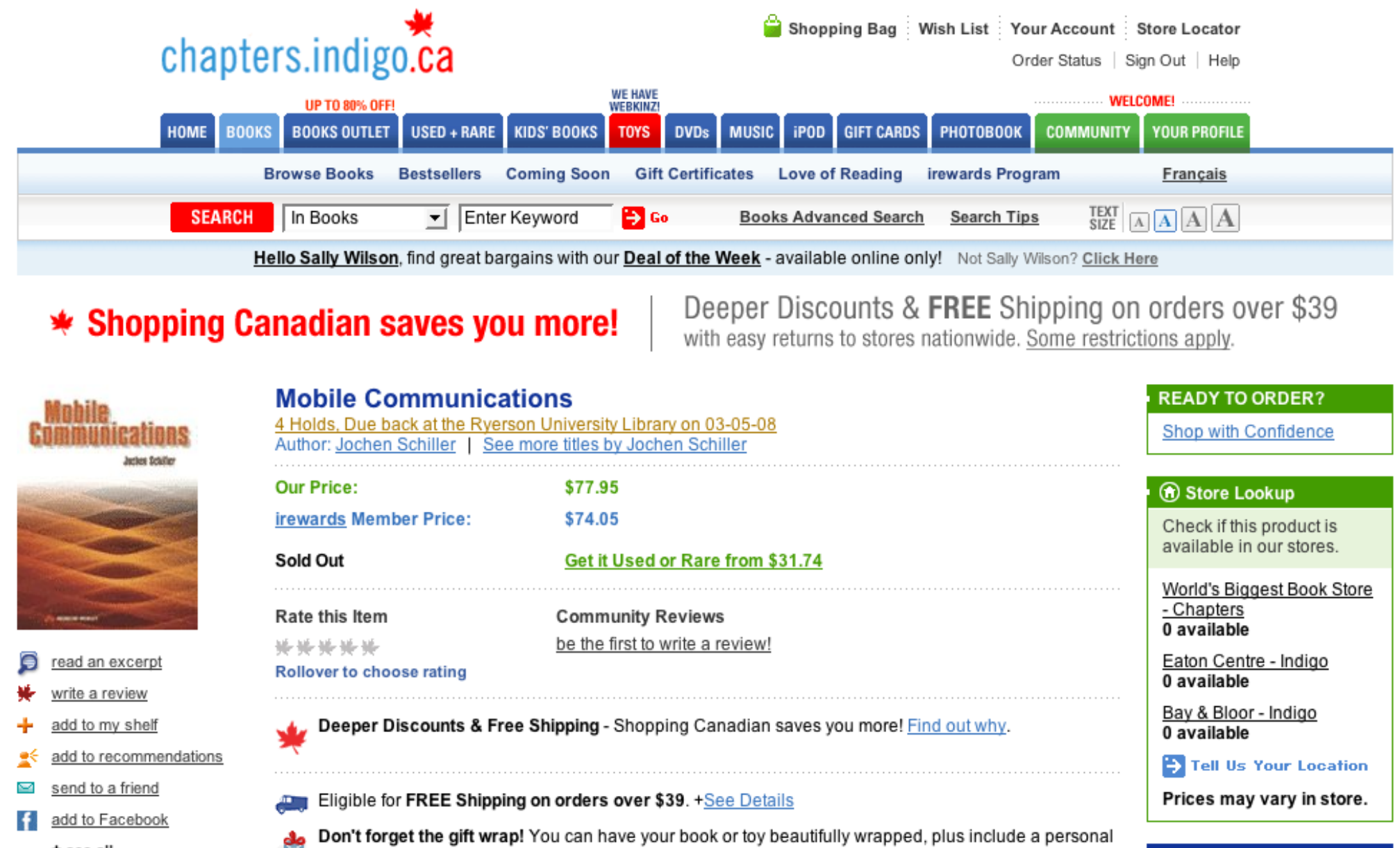




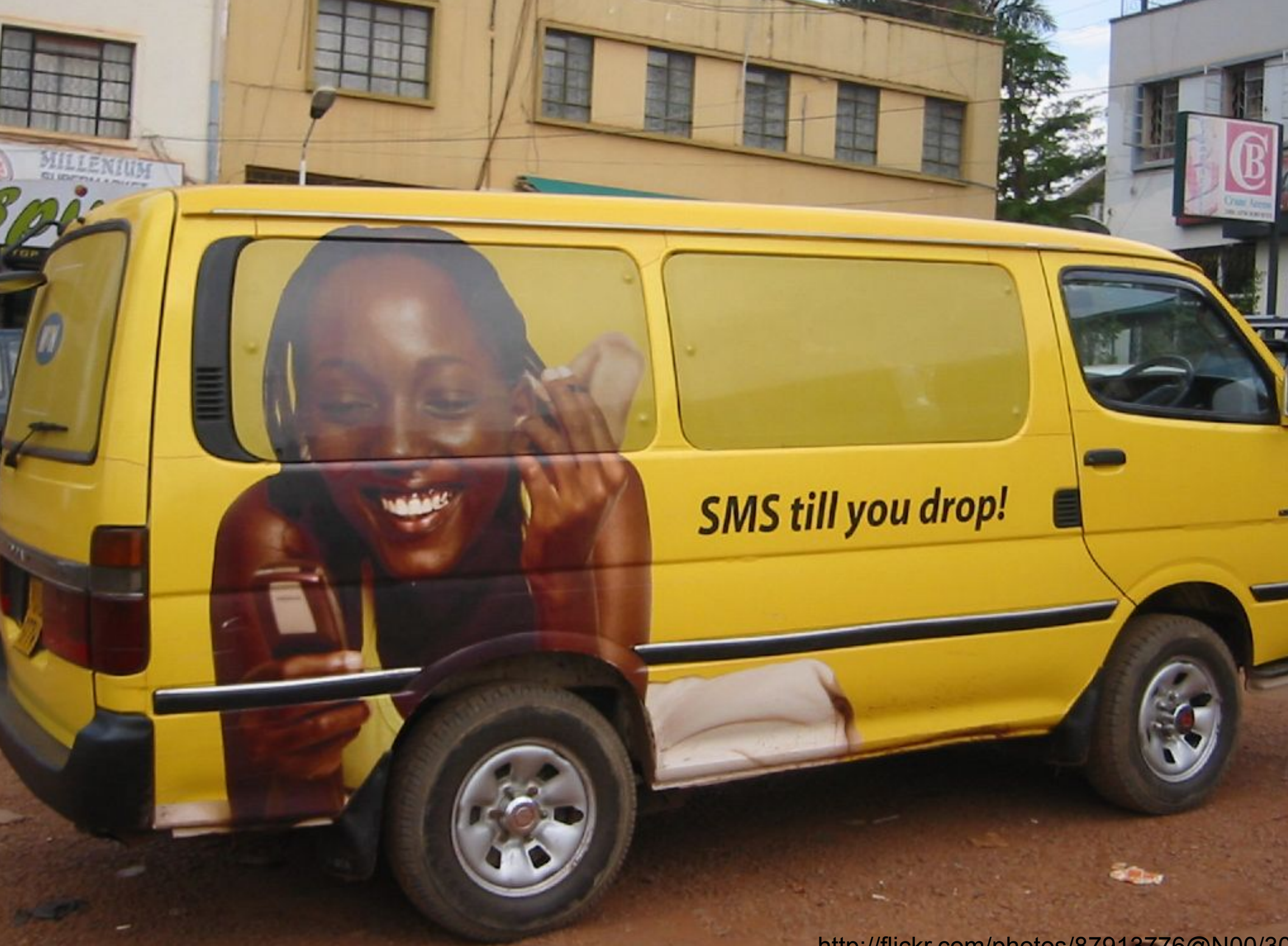

http://flickr.com/photos/87913776@N00/30 


\section{RYERSON UNIVERSITY}

Search this site:

\begin{tabular}{|c|c|c|c|c|c|}
\hline Catalogue & $\begin{array}{c}\text { Articles \& } \\
\text { Indexes }\end{array}$ & $\begin{array}{c}\text { Research } \\
\text { Help }\end{array}$ & $\begin{array}{l}\text { About the } \\
\text { Library/FAQ }\end{array}$ & $\begin{array}{c}\text { Interlibrary } \\
\text { Loans }\end{array}$ & $\begin{array}{c}\text { Map \& Data } \\
\text { Resources }\end{array}$ \\
\hline
\end{tabular}

me $>$ Catalogue

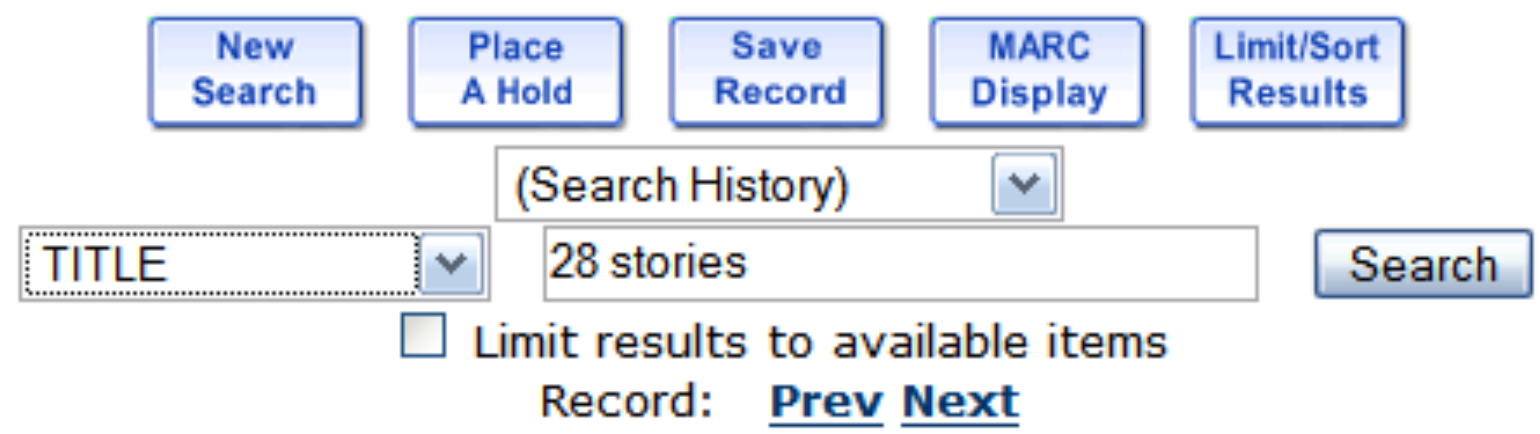

Author Nolen, Stephanie.

Title 28 : stories of AIDS in Africa / Stephanie Nolen.

Publisher Toronto: A.A. Knopf Canada, 2007.

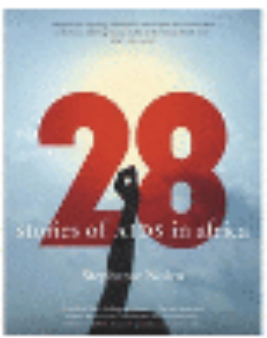

\begin{tabular}{|l|l|l|}
\hline LOCATION & CALL \# & STATUS \\
\hline 10th Floor & $\underline{\text { RA643.86.A35 N65 }}$ & DUE \\
& $\underline{\mathbf{2 0 0 7}}$ & $01-21-08$ \\
\hline
\end{tabular}

Description 407 p. : ill.

Notes Includes index.

Summary Twenty-eight anecdotal stories that chronicle men, women, and children involved in every aspect of the African AIDS crisis.

Subject AIDS (Disease) -- Africa. 
Title: Red moon rising : Sputnik and the hidden rivalries that ignited the Space Age / Matthew Brzezinski.

Call \#: TL789.8.U5 B784 2007

Floor: 10th

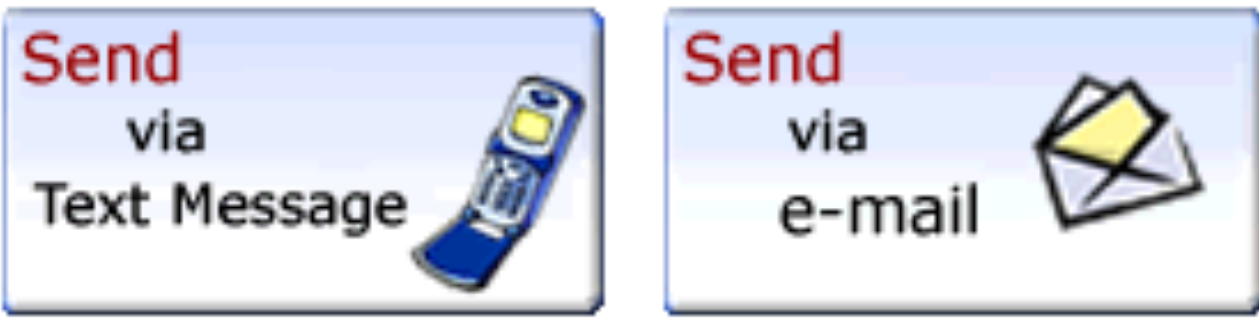

(i) 


\section{Send SMS Message}

Title: Red moon rising : Sputnik and the hidden rivalries that $\mathrm{i}$

Call \#: TL789.8.U5 B784 2007

\section{Floor Location: 10 th}

Select Service

Provider:

Cell Phone \#: $\square$ eg. 4161231234

NOTE: carrier charges may apply

Go Back 


\section{MOTOROLA}

[.د.

9 Vilessage 40

ryersonlibraryeryerson.ca(h

ye-Lib Item Info)

Tittle: The ghost map : the

story of London's most

terrifying epidem

Call \#: RC133.G5 J64 20006

Floor: 10th

BhCK

E

RFPLY 


\section{Messaging from the Catalogue}

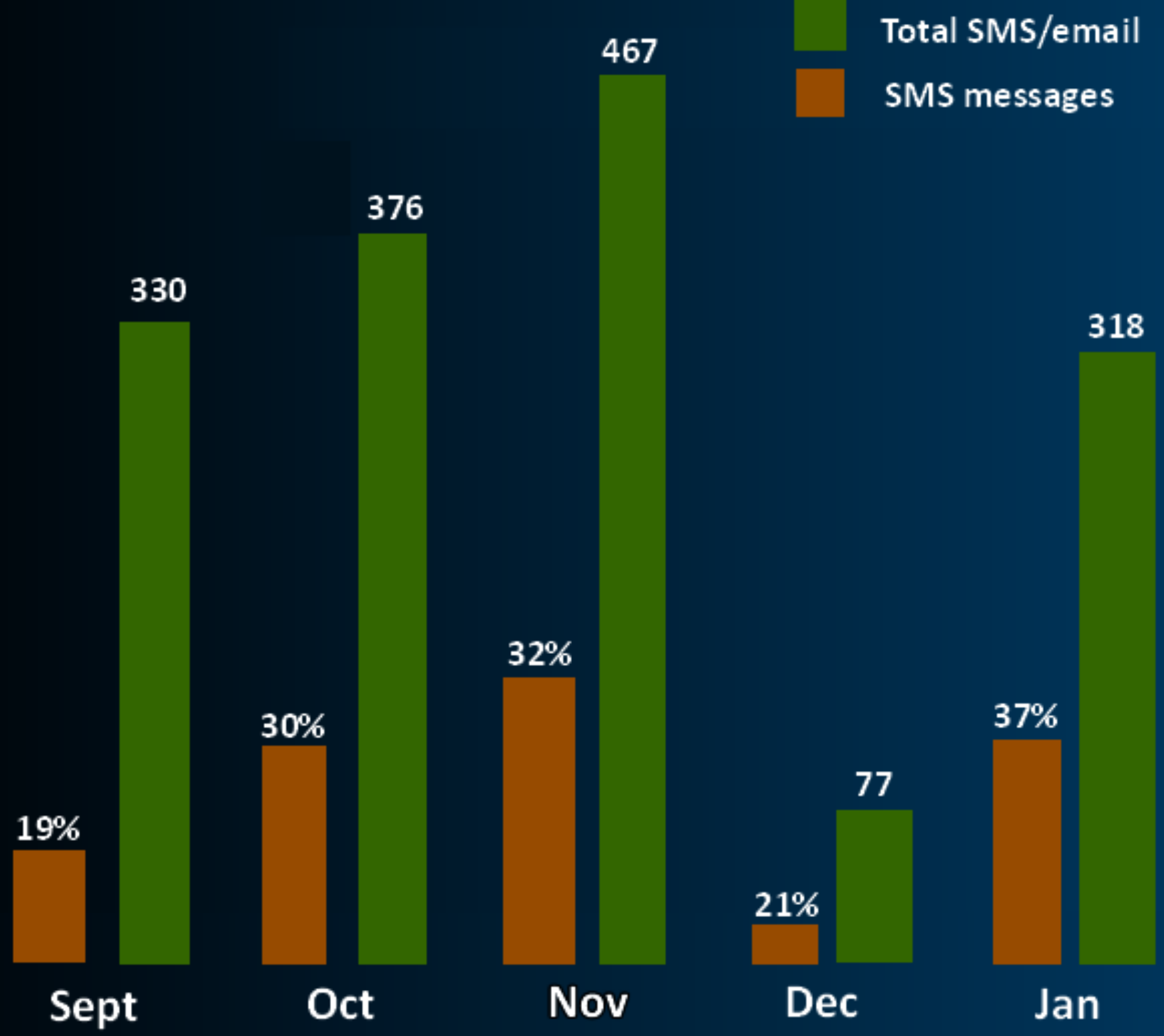



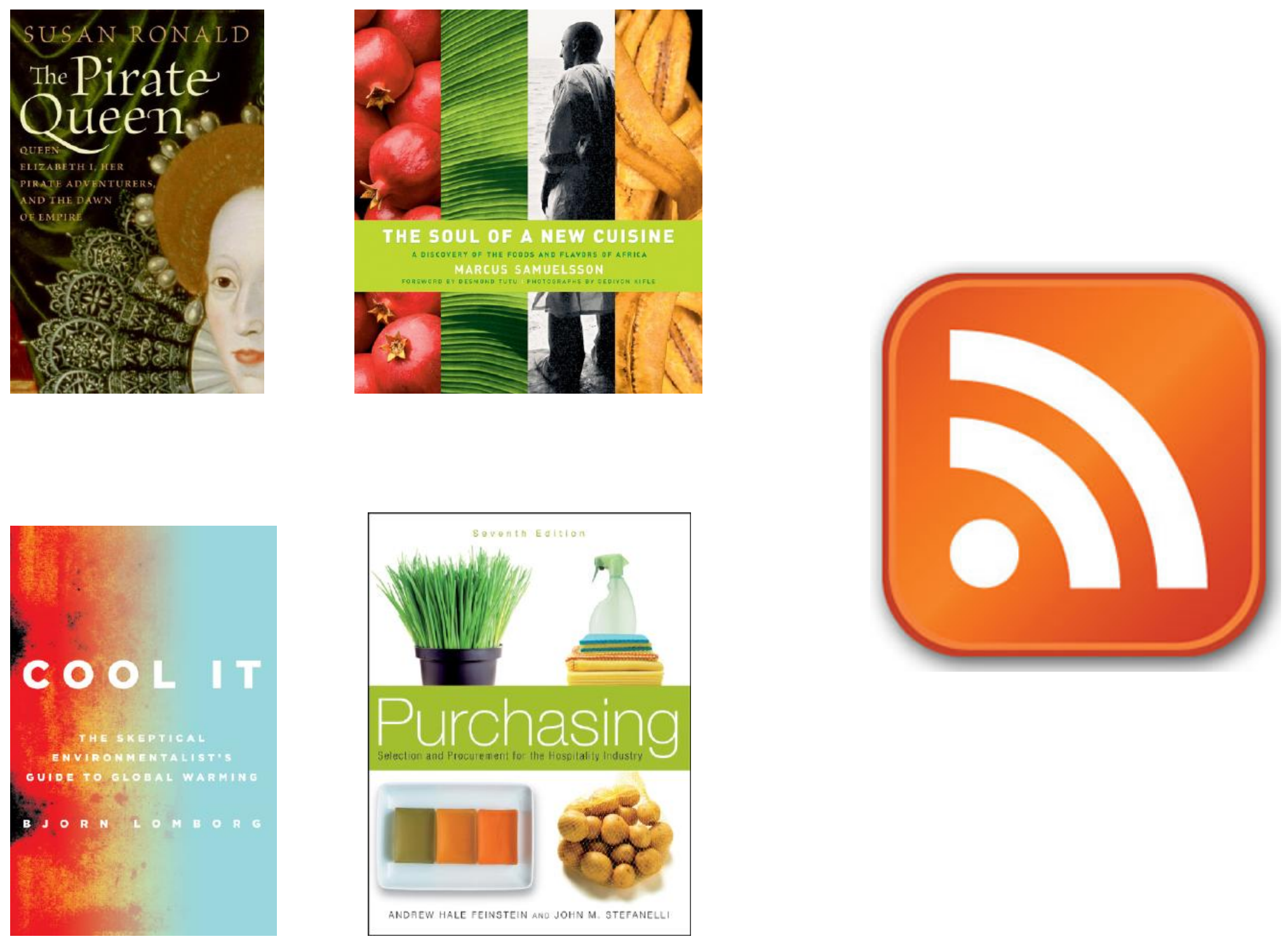


\section{RYERSONUNIVERSITY}

\section{Catalogue \\ Articles \& Indexes \\ Research Help}

LIBRARY

Search this site:

Search

Ask a

About the Library/FAQ
Interlibrary Loans
Map \& Data Resources
Home $>$ New Titles

\section{New Titles : (admin)}

\section{Set Date Range:}

1 month

\section{Search For:}

\section{Go}

LC Classification Guide

\section{Browse}

By Popularity

By Topic

By Faculty

« Faculties

« Arts

Geography (78) 요

\section{New Titles for the month of January 2008}

\section{Search Criteria \\ (2) By Faculty: Arts \\ Q By Subject: Geography}

\section{Results:}

Showing 1 - 10 of 78 Items.

Sort by (Title) (Author) (Call Number)

[ First / Previous / Next / Last ] Show per page: $(10)(25)(40)$
1.

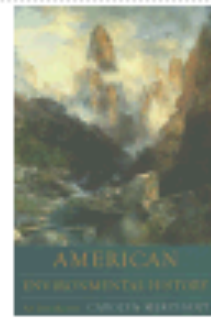

2. monbenters

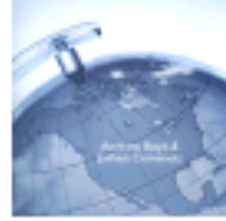

American environmental history: an introduction by: Merchant, Carolyn.

GF503 .M47 2007

ISBN: 9780231140355

Available in the Library!

An atlas of world affairs by: Boyd, Andrew, 1920-

G1035 .B6 2007

ISBN: 9780415391696

Available in the Library!

\section{๑}

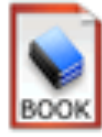


RYERSON UNIVERSITY

\section{Catalogue \\ Articles \& Indexes \\ Research Help}

LIBRARY

Search this site:

About the Lbrary/FAQ
Interlibrary Loans
Map \& Data Resources
Ask a Lbrarian
Home $>$ New Titles

New Titles : (admin)

Set Date Range:

1 month

Search For:

\section{Go}

\section{LC Classification Guide}

\section{Browse}

\section{By Popularity}

By Topic

By Faculty

Communication ... (13)

Community Serv... (1)

By Format

Ront (16)

\section{New Titles for the month of January 2008}

\section{Search Criteria \\ Q By Topic > N Visual Arts \\ Q By Keyword: architecture}

\section{Browse Topics:}

\begin{tabular}{l|l} 
N $1-9999$ Visual Arts (2) & NA Architecture (15)
\end{tabular}

Results:

Showing 1 - 10 of 17 Items.

Sort by (Tit/e) (Author) (Call Number)

[ First / Previous / Next / Last ] Show per page: (10) (25) (40)

1.

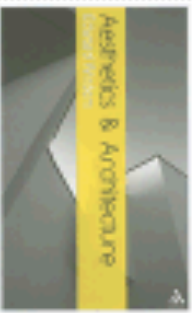

2.

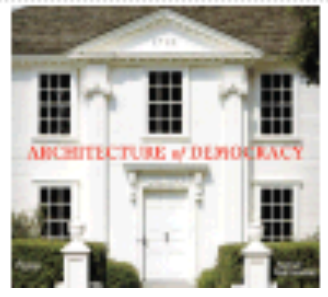

Aesthetics and architecture

by: Winters, Edward.

NA2500. W55 2007

ISBN: 9780826486325

Available in the Library!

The architecture of democracy: American architecture and the leqacy of the Revolution

by: Greenberg, Allan.

NA705,G69 2006

TSRN. 978ח84782793n 


\section{New Titles - Statistics}

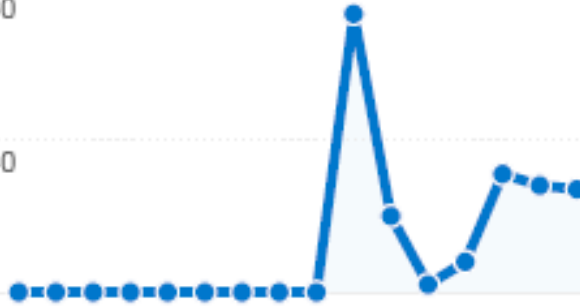

Jan 2008

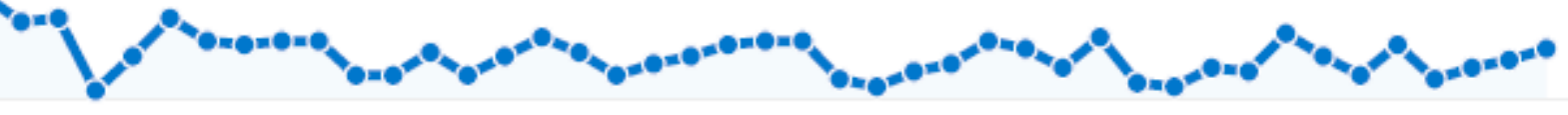

Feb 2008

Most popular sections

Main Page -645 views

DVDs - 90 views 


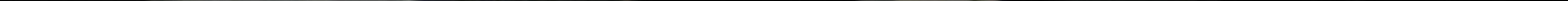



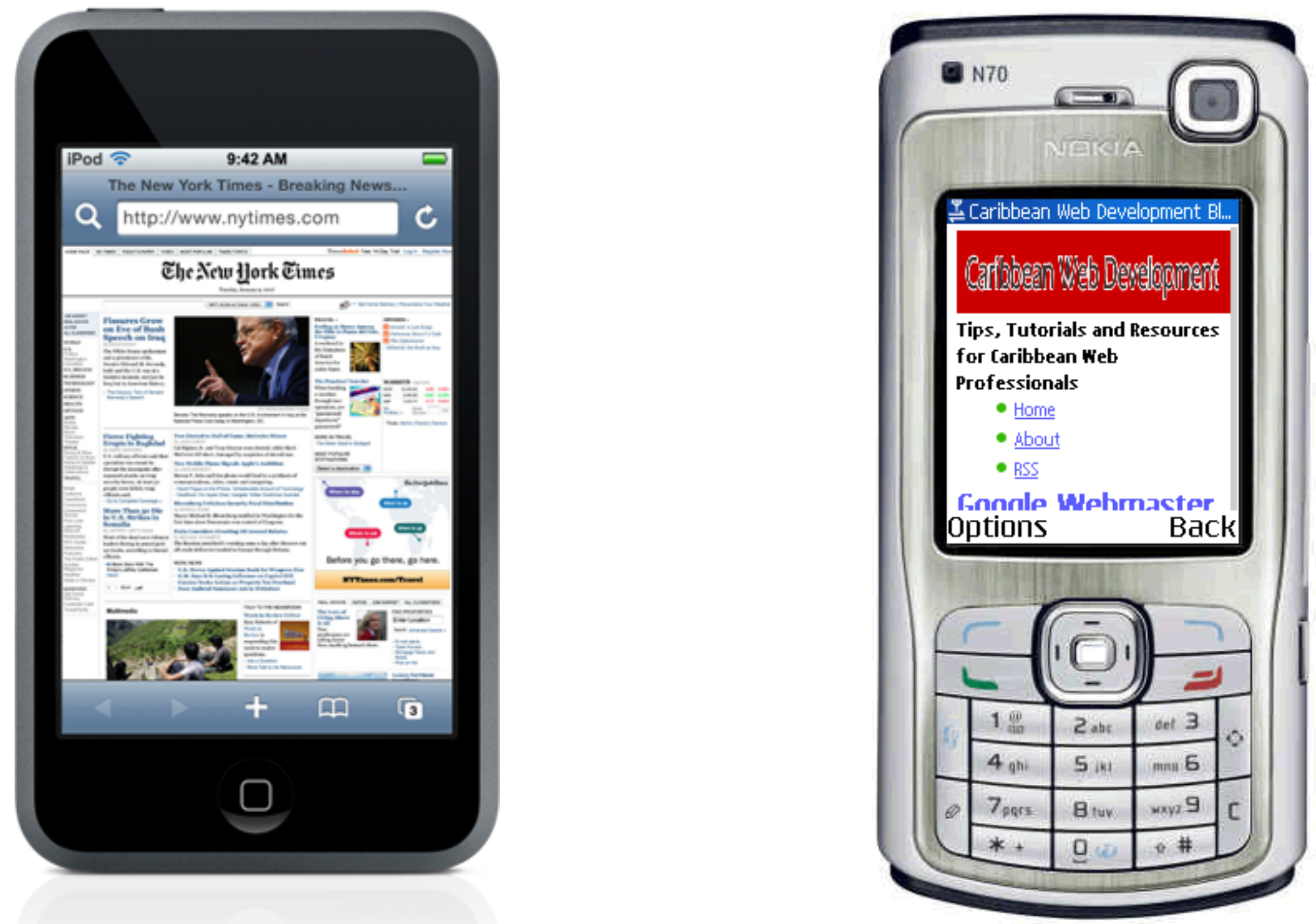
